Article

\title{
A Fifty-Year Sustainability Assessment of Italian Agro-Forest Districts
}

\author{
Fabio Recanatesi ${ }^{1}$, Matteo Clemente ${ }^{2, *}$, Efstathios Grigoriadis ${ }^{3}$, Flavia Ranalli ${ }^{4}$, Marco Zitti ${ }^{4}$ \\ and Luca Salvati ${ }^{4}$
}

Received: 14 November 2015; Accepted: 25 December 2015; Published: 30 December 2015

Academic Editor: Iain Gordon

1 Department of Agriculture, Forest, Nature and Energy (DAFNE), University of Tuscia,

Via S. Camillo de Lellis snc, Viterbo I-01100, Italy; fabio.rec@unitus.it

2 Department of Civil and Environmental Engineering, University of Perugia, Via G. Duranti, 93, Perugia I-06125, Italy

3 Department of Architecture and Project, La Sapienza University of Rome, Via Flaminia 359, Rome I-00196, Italy; stathis.grigoriadis@uniroma1.it

4 Council for Agricultural Research and Economics (CREA), Via della Navicella 2-4, Rome I-00184, Italy; ornata99@yahoo.it (F.R.); marcozitti@libero.it (M.Z.); bayes00@yahoo.it (L.S.)

* Correspondence: matteo.clemente@uniroma1.it; Tel.: +39-06-80691801; Fax: +39-06-80665622

\begin{abstract}
As cropland management and land use shifted towards more intensive practices, global land degradation increased drastically. Understanding relationships between ecological and socioeconomic drivers of soil and landscape degradation within these landscapes in economically dynamic contexts such as the Mediterranean region, requires multi-target and multi-scalar approaches covering long-term periods. This study provides an original approach for identifying desertification risk drivers and sustainable land management strategies within Italian agro-forest districts. An Environmental Sensitivity Area (ESA) approach, based on four thematic indicators (climate, soil, vegetation and land-use) and a composite index of desertification risk (ESAI), was used to evaluate changes in soil vulnerability and landscape degradation between the years 1960 and 2010. A multivariate model was developed to identify the most relevant drivers causing changes in land susceptibility at the district scale. Larger districts, and those with a higher proportion of their total surface area classified as agro-forest, had a significantly lower increase in land susceptibility to degradation during the 50 years when compared with the remaining districts. We conclude that preserving economic viability and ecological connectivity of traditional, extensive agricultural systems is a key measure to mitigate the desertification risk in the Mediterranean region.
\end{abstract}

Keywords: vulnerability; soil degradation; environmental indicators; desertification; Italy

\section{Introduction}

Agricultural systems evolved over centuries without exerting a significant impact on natural ecosystems [1]. The increased demand for food, fiber and fuel products has led to a rapid change in land use and to the progressive transformation of traditional agronomic techniques into high-input methods of land-resource exploitation [2,3], with a negative impact on non-renewable natural resources such as soil [4-6]. Since the industrial age, increasing pressure on crop production has been observed in developed countries with implications for the ecological sustainability of agricultural systems and the quality of the environment [7-10]. In Europe, non-urban landscapes are dominated by agricultural land, covering nearly $45 \%$ of the continental surface area [11], in part because agricultural systems intensified in the aftermath of World War II as a response to increased food demand, technological changes and developmental policies. In particular, the European Common Agricultural Policy (CAP) 
stimulated farmers to increase production efficiency [12-15]. The resulting changes in the use of land, cropping practices and socioeconomic characteristics of local communities have thus added to the progressive abandonment of marginal land, altering the structure and composition of rural landscapes [16-18].

This process determined a progressive fragmentation of cropland, incorporating sparse elements of natural vegetation in the most accessible areas (e.g., flat areas around large urban zones) and the expansion of forests in economically marginal and less accessible regions (e.g., upland and depopulated mountainous districts), with different modalities all over Europe [9,19-22]. With agricultural systems becoming more intensive, fragmented and on a smaller scale, landscape diversity usually decreases [23-25]. At the same time, socio-environmental rural systems may lose part of their ecological functionality due to the consumption of fertile soils driven by the so-called "land grabbing", described as a "global land rush for access to natural resources" $[1,2,26]$. Taken together, the decline in the complexity of terrestrial ecosystems and the consequent reduction of biological productivity are considered relevant factors of land degradation [27]. These processes include changes related to soil, landscape, vegetation and water, with negative societal and environmental impacts $[12,28,29]$.

The increasing demand for food, water and energy due to the rising human population will cause further intensifying pressure on land [7,30,31], with severe degradation of the most fertile soils resulting in a progressive loss of agricultural productivity and hence reduction of food provision [32-34]. At the same time, declining ecological complexity can alter the resilience of smaller systems, with a reduced capacity to mitigate the impact of environmental stresses or to adapt to them [35]. Changes in socio-environmental systems require further research linking ecological processes, land-use dynamics and a deeper knowledge of the functioning of economic markets and human decision-making processes [36]. Moreover, raising awareness among public and policy makers about the changes to the Earth's surface is a prerequisite of any policy against soil consumption and land degradation [37].

Land degradation is mainly human induced in the Mediterranean region [38] and triggers relevant processes of desertification in sensitive areas [39], causing a loss in the ecological complexity of socio-ecological systems [40], with more pronounced effects in semi-arid or dry climate conditions [30,41,42]. In particular, Mediterranean countries are vulnerable to climate change $[6,34,43]$ and soil degradation [32,44,45]. Planning for sustainable agricultural systems takes into account the management of land-use change related to soil erosion, groundwater resource depletion, loss of biodiversity, ecosystem services, traditional cropping systems and cultural landscapes [46-49]. In dynamic contexts such as the Mediterranean region, the relationship between ecological and socioeconomic factors driving soil degradation and desertification risk requires an in-depth investigation using multi-target and multi-scalar monitoring approaches [50-52].

Based on these premises, it is important to guarantee a continuous and updated local-scale monitoring of land degradation [53]. Large-scale frameworks are also relevant when informing local policies [54-56]. Permanent monitoring of (biophysical and socioeconomic) conditions for sustainability is particularly required for environmental systems such as the homogeneous agro-forest districts. The present study proposes an indicator-based approach outlining latent socio-ecological dynamics according to the level of land susceptibility to degradation and selected characteristics of the agro-forest local systems, including size of homogeneous rural districts and landscape composition [52]. Susceptibility refers to the stress to which a land unit is exposed and to its sensitivity to rapidly changing external factors [57], in particular the potential for loss or harm [58]. By applying to the Mediterranean region the Environmental Sensitivity Area (ESA) approach, the most common procedure for estimating land susceptibility to degradation, long-term changes were measured [41]. An indicator system composed of a large set of variables estimating soil, climate, vegetation and land use has been developed within the ESA framework [59]. Indicators were analyzed for different years (1960, 1990, 2000 and 2010) through an exploratory data analysis at the spatial scale of agriculturally homogeneous districts in Italy. Italy has been considered a hotspot for soil susceptibility and desertification risk by the United Nations Convention to Combat Drought and Desertification (UNCCD) Annex IV [60]. 
Annex IV indicated that an increased portion of rural land has been classified as vulnerable to degradation in recent decades, due to the effects of climate change, a growing population and landscape modifications [52].

\section{Methods}

\subsection{Study Area}

The spatial unit considered in this study includes a number of homogeneous agricultural and forest districts in Italy $\left(301,330 \mathrm{~km}^{2}\right)$ with different environmental and socioeconomic characteristics (see Figure 1). Italy features a variety of climate regimes ranging from the semi-arid Mediterranean climate observed in Sicily to most humid and wet continental regimes found in northeastern Italy [61]. However, climate is generally mild with a dry and hot summer and a relatively wet winter in a large part of the country. While the precipitation rate increases with elevation (from a minimum of $400 \mathrm{~mm}$ per year in southern Sicily to a maximum of $1500 \mathrm{~mm}$ in Friuli-Venezia Giulia), air temperatures follow the reverse pattern [52]. Upland and mountainous areas cover respectively $42 \%$ and $35 \%$ of Italy. The natural land area (forests, pastures, wetlands, high-quality crop mosaic) increases with elevation. The diversity in soil, vegetation and landscapes reflected in an exceptionally high level of animal biodiversity, is the result of a long-standing interplay between natural and anthropogenic factors across Italy [59]. Italy is historically divided into three geographical areas (North, Central and South Italy) reflecting disparities in socioeconomic variables and natural resources [10]. The study area was partitioned into 773 agriculturally homogeneous districts (AHD) defined at the national level by the Italian National Statistical Institute [62] using general criteria for similarity in climate, topography, soil quality, vegetation characteristics and land suitability to cropping, forestry or grazing (Figure 1). Districts include a variable number of municipalities, usually ranging between 5 and 10. Northern Italy districts include areas belonging to the following Italian administrative regions: Valle d'Aosta, Piedmont, Lombardy, Trentino Alto-Adige, Veneto, Friuli-Venezia Giulia and Emilia Romagna; central districts belong to Tuscany, Umbria, Marche or Latium regions. Finally, the southern districts belong to Abruzzo, Molise, Campania, Basilicata, Calabria, Apulia, Sicily or Sardinia. This spatial domain proved to be useful when acquiring disaggregated statistical data on agriculture [63]. The AHDs define homogeneous areas as those bearing agricultural and forest characteristics; their size can vary since they are a reflection of the fragmentation of socio-ecological rural systems [61].

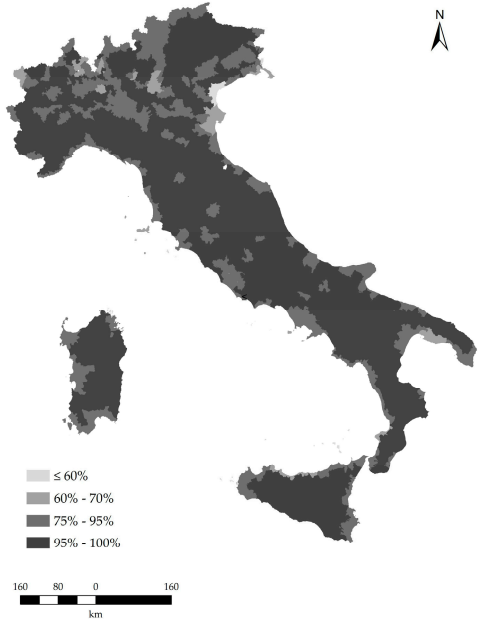

(a)

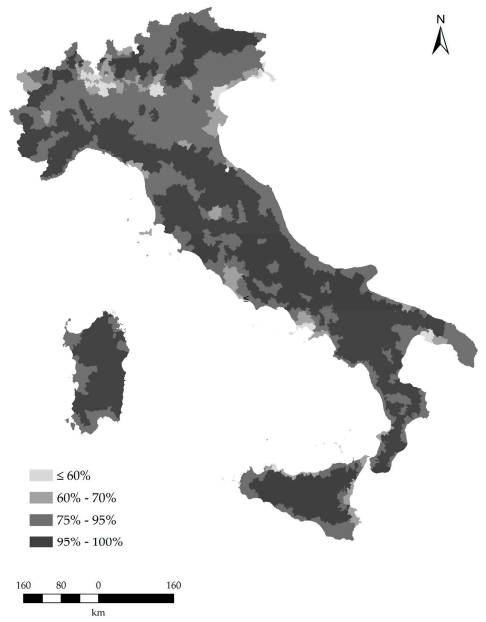

(b)

Figure 1. (a) Map of the Italian agro-forest districts illustrating the percentage of cropland and forests in the total district surface area for 1960; (b) Map of the Italian agro-forest districts illustrating the percentage of cropland and forests in the total district surface area for 2010. 


\subsection{Data and Variables}

The Environmentally Sensitive Area (ESA) approach, originally proposed in 1987, was adapted to monitor desertification risk on the behalf of the MEDALUS project [41]. Currently, the ESA framework is used to evaluate the susceptibility of land to desertification by incorporating variables that refer to four dimensions: climate, soil, vegetation and land-management quality [64]. The final result of the ESA framework is a composite index (hereafter ESAI) evaluating the level of land susceptibility to degradation in each elementary spatial domain. Flexibility in the use of the input variables, simplicity in the land classification system and stability over time and space in the composing indicators are the most appreciated features of the ESAI [52]. The level of land susceptibility was investigated for four years (1960, 1990, 2000 and 2010).

In the ESA framework, climate quality is assessed using the following variables: average annual rainfall rate and aridity index (both calculated on a ten-year basis using information collected in the Agro-Meteorological Database of the Italian Ministry of Agriculture) and aspect (derived from elaboration on the ASTER-Advanced Spaceborne Thermal Emission and Reflection Radiometer-Global Digital Elevation Model). Four time periods were investigated (1951-1960, 1981-1990, 1991-2000 and 2001-2010). Meteorological data were interpolated by way of kriging (rainfall) and co-kriging (air temperature) geo-statistical procedures (using elevation, latitude, and distance to the sea as ancillary variables) to ensure the homogeneous national coverage. A grid composed by 544 points with daily data of temperature, precipitation, humidity, solar radiation and wind were created.

Soil depth and texture, slope and the nature of the parent material are the variables considered in the ESA framework [46]. The soil data used in the present study were derived from the European Soil Database developed by the European Joint Research Centre (ISPRA, Italy) at a $1 \mathrm{~km}^{2}$ pixel resolution. Additional data sources include: (i) an Italian database of soil characteristics ("Map of the water capacity of agricultural soils") generated by the Ministry of Agriculture and based on nearly 18,000 soil samples; (ii) thematic maps including Ecopedological and Geological maps of Italy, obtained from JRC and Italian National Geological Service); and (iii) a land-system map produced by the Italian National Centre of Soil Cartography (CNCP).

Four variables (vegetation cover, fire risk, protection offered by vegetation against soil erosion and the degree of resistance to drought shown by vegetation) were derived from elaboration on comparable land-use/land-cover maps including the CORINE Land Cover (CLC)-like "Topographic and Land Cover Map of Italy" (LUM60) and three maps dated respectively 1990 (CLC90), 2000 (CLC00) and 2006 (CLC06) and derived from the pan-European CORINE Land Cover initiative. A weighting system (ranging from 1 to 2 and derived from [61]) that classifies each observed land class (generally using the second or third level of CLC nomenclature), was applied to each studied variable according to the level of land susceptibility to degradation. Anthropogenic pressure and land-management quality have been assessed as the result of population and land-use dynamics [41]. Variables such as density and annual growth rate of the resident population were considered based on the National Censuses of Population and Households held by the Italian National Institute of Statistics [63]. Population increase (or decrease) was determined as the annual demographic change observed at the district scale over four time periods: 1951-1961, 1981-1991, 1991-2001 and 2001-2011. Finally, an indicator of land-use intensity was obtained by applying a weighting system (ranging from 1 to 2 and derived from [52]) that classifies each land class according to the intensity of use. This indicator was obtained from elaboration on the maps described above (LUM60, CLC90, CLC00 and CLC06).

Four quality indicators of climate (CQI), soil (SQI), vegetation (VQI) and use of land (MQI) were estimated as the geometric mean of the different scores assigned to each input variable. Each indicator ranges from 1 (the lowest contribution to land vulnerability) to 2 (the highest contribution to land vulnerability). The ESAI was then estimated in each spatial unit and year as the geometric mean of the four quality indicators (CQI, SQI, VQI, MQI) obtaining a score ranging from 1 (the lowest sensitivity to degradation) to 2 (the highest sensitivity to degradation). The four indicators were weighted 
the same in the ESA approach [42]. Maps have been produced at $1 \mathrm{~km}^{2}$ pixel resolution [59]. The elementary spatial unit has been selected according to [52] and is coherent with the resolution of the individual layers considered here. Four classes were identified that reflect the most used classification thresholds [41]: unsusceptible areas (ESAI < 1.17); areas potentially susceptible to land degradation $(1.17<$ ESAI < 1.225) and areas susceptible to land degradation further divided in two classes: "fragile" areas $(1.225<$ ESAI < 1.375) and "critical" areas $(\mathrm{ESAI}>1.375)$.

\subsection{Data Analysis}

A total of 12 indicators were considered in the present study at the AHD scale: average and coefficient of variation of the ESAI score (ESAI and ESAIcv), percent annual change in the ESAI ( $\triangle \mathrm{ESAI}$ ), mean score of the four thematic indicators (CQI, SQI, VQI, MQI), percentage of "critical" land (ESAI > 1.375) in the total AHD surface area (CRI), mean elevation (ELE), latitude (based on a 0-1 dummy variable discriminating northern/central Italy districts from southern Italy districts: LAT), total AHD surface area (SupTot) and the percentage of agricultural and forest land area in the total AHD surface area (SupAgr). The spatial distribution of selected indicators was mapped in Figures 1 and 2. A non-parametric Spearman correlation analysis was run with the objective to identify the indicators with the highest spatial association with the average level of land susceptibility (ESAI) and the rate of change in the ESAI score ( $\triangle \mathrm{ESAI}$ ) for each district by time period (1960-1990, 1990-2000, 2000-2010). For each pair-wise comparison, statistical significance was set up at $p<0.05$ after Bonferroni's correction for multiple comparisons. The environmental indicators assessing the level of land susceptibility to degradation (ESAI, ESAIcv, CQI, SQI, VQI, MQI, CRI) were derived from the overlapping of the ESA raster maps with the shape-file representing the boundaries of the Italian AHD disseminated by Istat on the basis of the "zonal statistics" tool provided with the ArcGIS package (ESRI Inc, Redwoods, CA, USA), which computes a surface-weighted average of each variable's values belonging to the $\mathrm{i}$-th spatial domain.

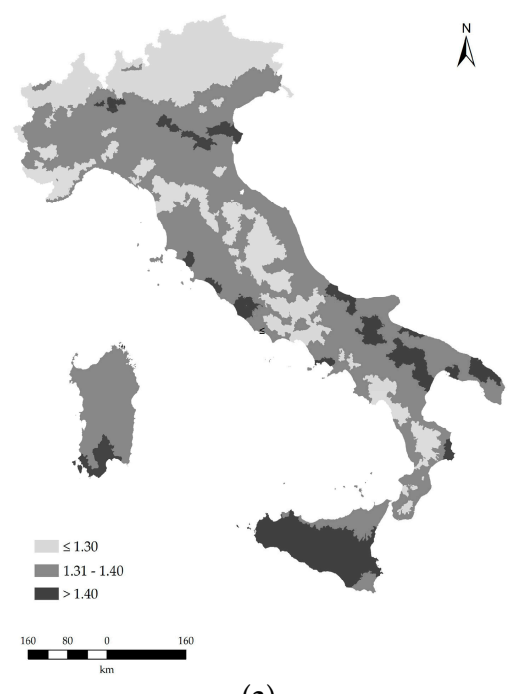

(a)

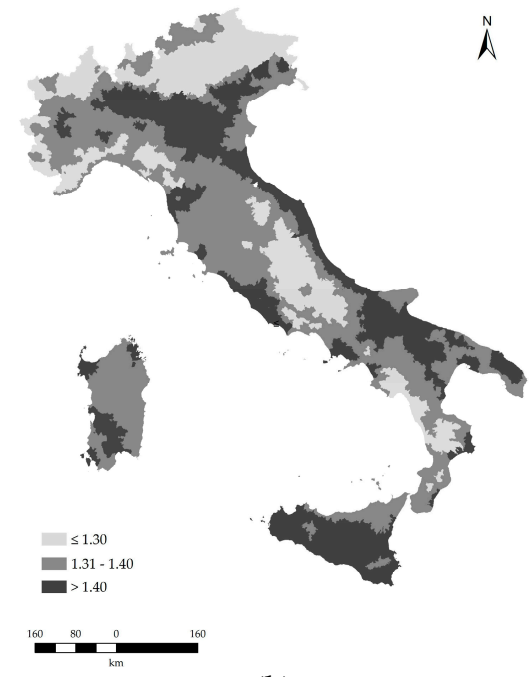

(b)

Figure 2. (a) The level of land susceptibility to degradation in the Italian rural districts measured by the average ESAI score for 1960; (b) The level of land susceptibility to degradation in the Italian rural districts of Italy measured by the average ESAI score for 2010.

Spearman non-parametric correlations were also run to study the pair-wise correlation between $\triangle \mathrm{ESAI}$ and the percent share of three land cover classes (annual and perennial cropland, pastures and crop mosaic and forests) in the total district area for each time period investigated. These indicators were derived by grouping the respective CORINE Land Cover classes belonging to CLC first-digit Classes 2 and 3 at each relevant time point. The accumulated surface area of the three classes provided 
the base to calculate the SupAgr indicator (see above). The surface area of annual and perennial crop was considered a proxy for intensive agriculture. For each pair-wise comparison, statistical significance was set up at $p<0.05$ after Bonferroni's correction for multiple comparisons.

A multiple linear regression was finally run to identify (and rank the importance of) the indicators most associated with the percentage change in the level of land susceptibility for each district and time period. The model was developed using a forward stepwise approach with seven predictors (ESAI, ESAIcv, CRI, ELE, LAT, SupTot, SupAgr) and $\triangle$ ESAI as the dependent variable. Predictors were included in the model when the $p$-level associated with the respective Fisher-Snedecor test was below 0.01 . Results of the regression model were illustrated using standardized coefficients $(\beta)$ and tests of significance for the whole model (an overall Fisher-Snedecor's F-statistic testing for the null hypothesis of non-significant model) and for each predictor separately (a Student's $t$-statistic testing for the null hypothesis of non-significant regression coefficient). A Durbin-Watson test for the null hypothesis of serially uncorrelated errors was applied separately to regression residuals.

\section{Results}

\subsection{Correlating the Environmental Sensitivity Area Index (ESAI) with Selected Spatial Indicators}

Results of a Spearman pair-wise non-parametric correlation between the average level (or the annual percent change) of land susceptibility to degradation (ESAI and $\triangle E S A I$ ) and selected contextual indicators, are shown in Table 1 . The average ESAI score increased mainly with the percentage of land classified as "critical" - with correlation coefficients increasing between $1960\left(r_{s}=0.74\right)$ and 2010 $\left(r_{s}=0.84\right)$-and decreasing with the mean district elevation, with coefficients showing the opposite pattern $\left(r_{s}=-0.54\right.$ and -0.68 , respectively, for 1960 and 2010). Land susceptibility increased in southern Italy districts (especially those located in Sardinia, Sicily and Apulia regions) but the association with latitude was milder in recent decades $\left(r_{s}=0.43\right.$ and 0.18, respectively, for 1960 and 2010). The ESAI scores increased also with CQI, VQI and MQI, while remaining unaffected by the SQI. The extent of "critical" land (CRI) was one of the indicators correlating most with the ESAI score at the district scale. While the percentage of agro-forest land in the total district area correlated negatively with the ESAI (with coefficients increasing over time from $r_{s}=-0.13$ for 1960 to $r_{s}=-0.35$ for 2010), the level of susceptibility to degradation was unaffected by the size of rural districts.

Table 1. Spearman pair-wise non-parametric correlation coefficients between level (ESAI) or percent change over time $(\triangle \mathrm{ESAI})$ in land susceptibility to degradation and selected indicators.

\begin{tabular}{|c|c|c|c|c|c|c|c|c|c|c|c|}
\hline \multirow{2}{*}{ Variable } & \multicolumn{7}{|c|}{ ESAI Predictors * } & \multicolumn{4}{|c|}{ ESAI Partial Indicators* } \\
\hline & LAT & ELE & ESAI & ESAIcv & CRI & SupTot & SupAgr & CQI & SQI & VQI & MQI \\
\hline \multicolumn{12}{|c|}{ Level of land susceptibility to degradation (ESAI) } \\
\hline 1990 & 0.36 & -0.66 & - & -0.14 & 0.77 & 0.15 & -0.23 & 0.68 & 0.04 & 0.79 & 0.60 \\
\hline 2000 & 0.42 & -0.64 & - & -0.13 & 0.82 & 0.13 & -0.22 & 0.69 & 0.09 & 0.75 & 0.59 \\
\hline 2010 & 0.18 & -0.68 & - & -0.24 & 0.84 & 0.09 & -0.35 & 0.62 & 0.02 & 0.79 & 0.68 \\
\hline $1990-2000$ & 0.25 & -0.03 & -0.01 & 0.12 & 0.03 & -0.04 & -0.01 & -0.02 & 0.16 & -0.01 & -0.10 \\
\hline $2000-2010$ & -0.41 & -0.12 & -0.09 & -0.09 & -0.19 & -0.18 & -0.34 & -0.39 & -0.13 & 0.10 & 0.23 \\
\hline
\end{tabular}

Changes over time in the average district ESAI score during the first time period examined (1960-1990) were associated negativelywith elevation $\left(r_{s}=-0.50\right)$ and SQI $\left(r_{s}=-0.23\right)$, while increasing moderately with the average ESAI $\left(r_{s}=0.18\right)$, CQI $\left(r_{s}=0.20\right)$ and MQI $\left(r_{s}=0.29\right)$ at the beginning of the time period studied. Between 1990 and 2000, $\triangle$ ESAI increased with latitude $\left(r_{s}=0.25\right)$. During the most recent decade (2000-2010), $\triangle \mathrm{ESAI}$ increased with the MQI $\left(r_{s}=0.23\right)$ and decreased with 
latitude $\left(r_{s}=-0.41\right)$; the percentage of "critical" land in the total district area was $\left(r_{s}=-0.19\right)$, CQI score $\left(r_{s}=-0.39\right)$, district size $\left(r_{s}=-0.18\right)$ and the percentage of the agro-forest surface area in each district $\left(r_{s}=-0.34\right)$.

\subsection{Correlating Changes over Time in Land Susceptibility with Selected Land Cover Variables}

Table 2 shows the correlation between changes over time in land susceptibility to degradation $(\triangle \mathrm{ESAI})$ and the percent share of selected land-cover classes in the total district area. A higher probability of increases in the level of land susceptibility was found in districts with a relevant proportion of annual and perennial cropland, mainly in the first time period $\left(r_{s}=0.29\right.$ in 1960-1990). Districts with a higher proportion of forest land experienced a lower $\triangle \mathrm{ESAI}$ in 2000-2010 $\left(r_{s}=-0.26\right)$. A decreasing $\triangle \mathrm{ESAI}$ was observed over 2000-2010 in districts with a higher proportion of both forests $\left(r_{s}=-0.31\right)$ and pastures/crop mosaics $\left(r_{s}=-0.20\right)$.

Table 2. Spearman pair-wise non-parametric correlation coefficients between changes over time in land susceptibility to degradation ( $\triangle \mathrm{ESAI})$ and selected land-cover variables (see Section 2.3 ).

\begin{tabular}{lccc}
\hline \multirow{2}{*}{ Variable } & \multicolumn{2}{c}{ Percent Share of Each Cover Class Area in the Total District Area * } \\
\cline { 2 - 4 } & $\begin{array}{c}\text { Annual and Perennial Cropland } \\
\text { (CLC 2.1 + 2.2) }\end{array}$ & $\begin{array}{c}\text { Pastures and Crop Mosaic } \\
\text { (CLC 2.3 + 2.4) }\end{array}$ & Forest (CLC 3.1) \\
\hline $1960-1990$ & 0.29 & -0.05 & -0.14 \\
$1990-2000$ & 0.16 & -0.15 & $-\mathbf{0 . 2 6}$ \\
2000-2010 & $-\mathbf{0 . 2 0}$ & $-\mathbf{0 . 3 1}$ \\
\hline * Depending on the availability of Corine Land Cover (CLC) maps, variables refer to the end of each observation \\
period for changes in the level of land susceptibility to degradation (i.e., 1990 for 1960-1990, 2000 for 1990-2000 \\
and 2006 for 2000-2010). Bold indicates significant coefficients at $p<0.05$ after Bonferroni's correction for \\
multiple comparisons.
\end{tabular}

\subsection{Identifying Drivers of Changes in the Level of Land Susceptibility}

$\triangle \mathrm{ESAI}$ was considered as the dependent variable in a forward stepwise regression with seven predictors (Table 3). Model's performance based on adjusted $R^{2}$ was higher for the first and last time periods. Results underlined the negative impact of the percentage of "critical" land (CRI) on the $\triangle \mathrm{ESAI}$ in both the first and the second time period ( $\beta=-0.23$ and -0.25 , respectively, for 1960-1990 and 1990-2000). A negative correlation between $\triangle E S A I$ and average district elevation was observed for the first $(\beta=-0.51)$ and the last time period $(\beta=-0.16)$. Latitude impacted the $\Delta$ ESAI with different regression coefficients during the second (1990-2000) and the third time period (2000-2010) with $\beta$ respectively equal to 0.36 and -0.37 . In the last decade, $\triangle E S A I$ decreased with the percentage of area covered by agricultural and forest land $(\beta=-0.10)$, thereby confirming the evidence provided by the Spearman correlation analysis (see Section 3.1).

Table 3. Forward stepwise regression results by year with the percentage change in the level of land susceptibility to degradation as dependent variable and selected predictors $\left({ }^{*}\right)$.

\begin{tabular}{|c|c|c|c|c|}
\hline Variable & $\beta$ & Std.Err. & $t_{(770)}$ & $p$-Level \\
\hline \multicolumn{5}{|c|}{$\triangle E S A I(1960-1990):$ Adjusted $R^{2}=0.27, F_{(2,770)}=142.0, p<0.0001$} \\
\hline Ele & -0.512 & 0.031 & -16.3 & $<0.001$ \\
\hline CRI & -0.230 & 0.031 & -7.3 & $<0.001$ \\
\hline \multicolumn{5}{|c|}{$\Delta E S A I(1990-2000):$ Adjusted $R^{2}=0.11, F_{(2,770)}=50.8, p<0.0001$} \\
\hline Lat & 0.357 & 0.037 & 9.6 & $<0.001$ \\
\hline CRI & -0.254 & 0.037 & -6.8 & $<0.001$ \\
\hline \multicolumn{5}{|c|}{$\Delta E S A I(2000-2010):$ Adjusted $R^{2}=0.17, F_{(3,769)}=55.0, p<0.0001$} \\
\hline Lat & -0.374 & 0.033 & -11.3 & $<0.001$ \\
\hline Ele & -0.157 & 0.033 & -4.8 & $<0.001$ \\
\hline SupAgr & -0.101 & 0.033 & -3.1 & 0.002 \\
\hline
\end{tabular}




\section{Discussion}

The Mediterranean region is particularly threatened by soil impoverishment driven by the intensification of agriculture and rapid landscape transformations [24]. The extent of land exposed to intense degradation has risen markedly with the shift of cropland management towards more intense practices and the consequent change in the use of land [55]. Karamesouti et al. [14] emphasized the relevance of comprehensive socio-ecological indicators to identify the peculiarity of rural systems characterized by crop mosaics, land-use diversification and natural biodiversity. The present study contributes to the analysis of land-use complex dynamics in Italian agro-forest districts and provides information for fine-tuned, sustainable land-management policies in a context of land degradation for the Mediterranean region. By exploring the complexity of local social-ecological systems, the synergic action of social and natural factors is crucial in determining the level of land susceptibility to degradation $[57,58,65]$.

The increased interest in soil degradation and land desertification processes is reflected in a number of methodologies and indicators evaluating the negative impact of biophysical and socioeconomic factors on Mediterranean dry lands [51,54,61]. Hermann and Hutchinson [39] attribute the main cause of land degradation to four dimensions: climate, vegetation, socioeconomic and political processes, all impacting the effectiveness of land-management practices. Wainwright [36] points out the need of positive and normative approaches linking ecological processes, land-use dynamics, economic markets and human decision making in order to raise awareness among public and policy makers about environmental changes [26]. Choosing a spatially disaggregated and homogeneous domain, such as the agro-forest districts in Italy, allows the development of an interpretative framework suited to analysis of the spatial-temporal evolution of complex socio-ecological systems [61].

Investigating the latent relationship between the level of land susceptibility to degradation and selected environmental and land-use indicators, allows the assessment of the long-term ecological trajectory of homogeneous rural systems and the identification of the most relevant socioeconomic drivers of change, based on the specificity of each district in terms of extension, geographical position and biophysical attributes. In fact, mainly in recent periods, the level of land susceptibility has moderately decreased in upland and mountain rural districts with a high proportion of agro-forest land in the total district area. The present study demonstrated that mixed but less fragmented forest-cropland systems located in larger rural districts have experienced moderate environmental changes reflected in a reduced increase in the level of land susceptibility to degradation. As a general trend, land susceptibility increased with both CQI and VQI. These results agree with previous studies carried out at different spatial and temporal scales in Italy [52,59,61]. Land susceptibility also increased with the MQI, underlying the importance of socioeconomic factors and political decisions on land-use patterns and processes [65]. Specifically, land susceptibility decreased in the case of pure forests, but also in districts with more diversified and mixed natural-agricultural landscapes including pastures and high-quality crop mosaics, as they are higher in rural districts with mono-specific, low-diversity cropping systems dominated by annual and/or perennial crops (Figure 3).
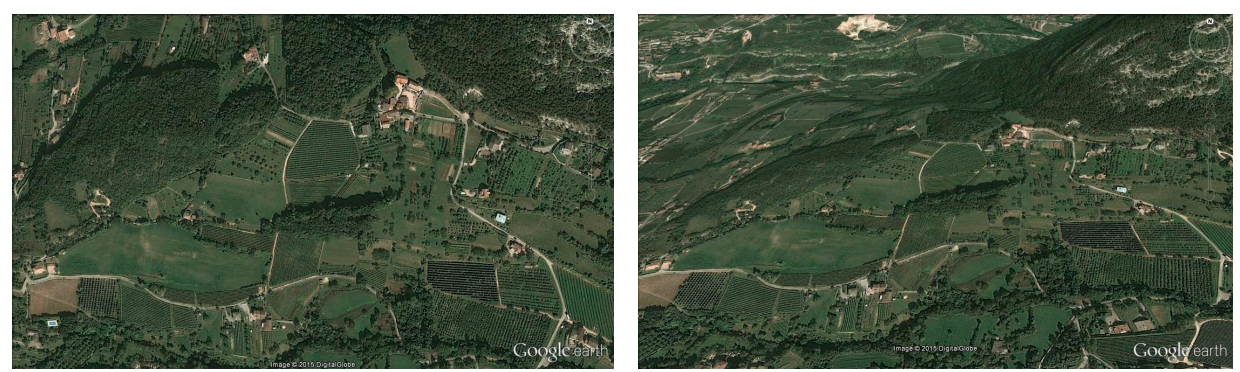

(a)

Figure 3. Cont. 

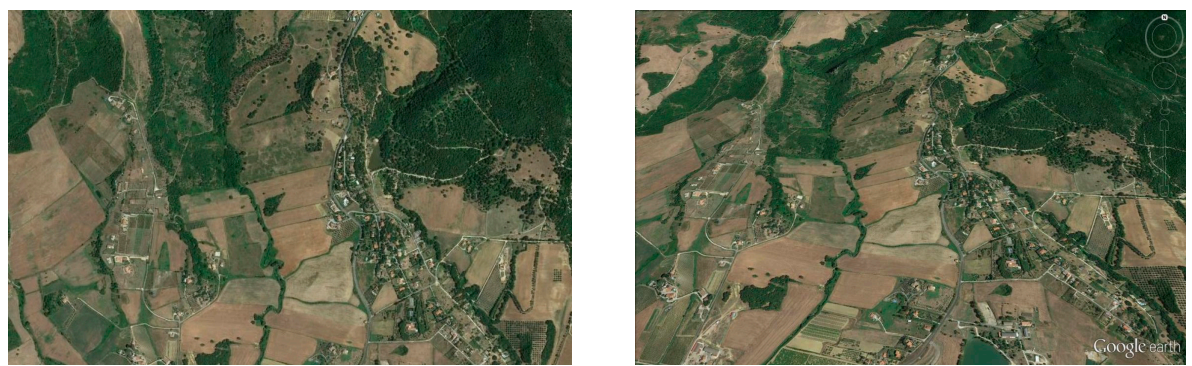

(b)
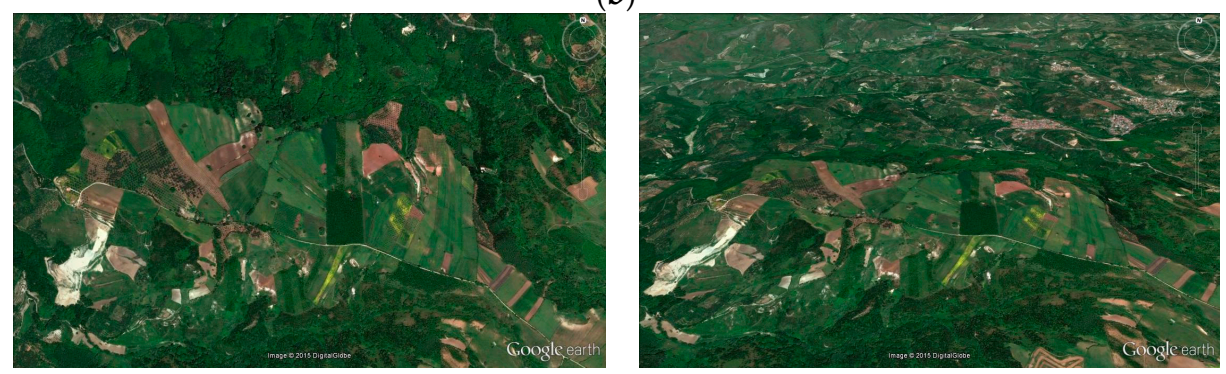

(c)
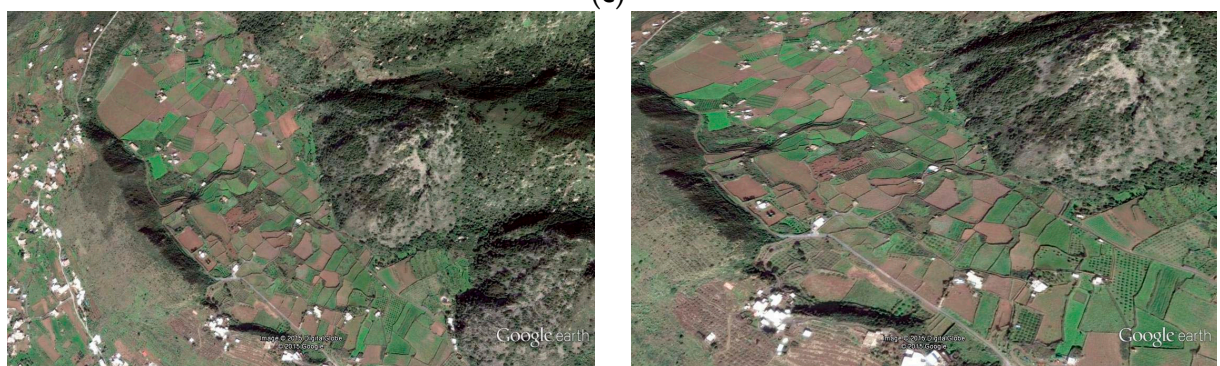

(d)

Figure 3. Pictures depicting high-quality crop mosaics and mixed agricultural-natural landscapes in Italy (photographs courtesy of Google Earth, 2015). (a) Orchards intermixed with pastures, wetlands and woodlots in the Alps (Trentino, northeastern Italy); (b) Mountain cropping systems (pastures and cereal crops) in the Apennines (Latium, central Italy); (c) Old-growth olive groves intermixed with garden crops and forest fragments in southern Italy (Calabria, southern Italy); (d) Traditional vineyards with unmanaged pastures and Mediterranean maquis in Pantelleria Island (Sicily).

The analysis of changes over time in the level of land susceptibility also indicates complex spatial patterns influenced by geographical gradients including elevation, latitude and the environmental attributes of each rural district reflected in the level of land susceptibility at the beginning of the study period [42]. Interestingly, size and degree of "rurality" in agricultural districts (intended as the share of cropland and forest in the total district surface area) impact significantly the spatial pattern of changes over time in the ESAI, especially in the last decade (2000-2010). Bigger districts, possibly with non-fragmented and more diversified landscapes, have shown a less rapid increase (or even a decrease) in the level of land susceptibility. This result was confirmed by the negative correlation observed between $\triangle \mathrm{ESAI}$ and the proportion of cropland and forests in each district. Loss in biodiversity and fragmentation of traditional cropping systems were proposed as important drivers of land degradation [23]; moreover, the patch-size distribution of natural vegetation or crop was considered a warning signal for the onset of desertification in dry rural systems under specific environmental and socioeconomic pressures such as overgrazing. From the normative point of view, administrative areas, spatial clusters or homogeneous regions (from both the environmental and socioeconomic point of views) are considered when implementing regional planning or monitoring environmental policy targets according to homogeneous land units. In rural areas characterized by traditional (and high-diversity) cropping systems such as those found in southern Europe, a 
permanent assessment of rural land-use patterns and drivers of change is required to identify the relationship between ecological and socioeconomic factors driving soil degradation risk over long-term periods $[15,51,64,66,67]$.

Identifying the characteristics of the local agro-forest systems that impact land susceptibility less allows for the speculation of the most effective land-management strategies for the sustainable planning of cropping systems. This evidence imposes the mitigation of land degradation as the final policy target in the medium-term [40]. The implementation of good practices on land protection in rural districts mainly depends on the adoption of legal frameworks and policies inducing stakeholders to make decisions against soil degradation $[28,29,60,68]$. While outlining the urgent need to stop land degradation, "The Future We Want" document of the Conference on Sustainable Development 2012 identifies the environmental policies that should be implemented by realistic and feasible indications towards sustainable rural systems [37].

Previous studies have demonstrated: (i) how policy analysis can be useful in measuring the effectiveness of strategies mitigating land degradation at the local scale; and (ii) how "effective" and "ineffective" measures can affect rural households' decisions to conserve or degrade their land [13]. Since farmers respond to local economic opportunities in ways that best suit the needs of their families and households, local changes may have a considerable impact on individual decisions influencing land degradation. In this sense, the relevance of local environmental changes is less well known compared to global or regional changes. Integrated analysis grounded in the specificity of traditional cropping systems and the socioeconomic profile of rural districts may better contribute to policies fine-tuned with the local context in mind. Widely supported measures promoting incentives towards sustainable agriculture should be adapted to the specificity of the existing cropping system. Mechanisms of environmental education, training and dissemination of technical information on sustainable use of soil resources are particularly effective when focusing on traditional agronomic practices already in use in the area. The implementation of sustainable practices suitable for increasing soil protection and reducing pollution, crop intensification and unsustainable mechanization requires economic incentives in rural districts with a population depending on an agricultural income [50].

\section{Conclusions}

The present study demonstrates how a simplified land classification system may contribute to large-scale monitoring that in turn inform local policies based on e.g., agricultural districts or spatial domains homogeneous in specific biophysical attributes. However, further investigation is needed to improve the informative capability of socio-environmental indicators and to provide a more detailed analysis of system conditions for sustainability over time in homogeneous agro-forest districts. To avoid conflicts between different approaches (e.g., land versus soil) assessing the desertification risk in the Mediterranean basin is imperative for the correct interpretation of complex environmental problems in dynamic rural systems [45]. In this sense, the use of a hierarchical and multi-scalar monitoring approach and the development of functional classifications of agricultural landscapes and social systems are important issues deserving further investigation. Proxy indicators assessing the demand for individual soil functions (e.g., as set by agri-environmental policies) and the supply of soil functions (e.g., as defined by land capability, soil attributes and land use) are also needed in this perspective. This study aims to provide a preliminary assessment of these dimensions in Italy by using a relevant spatial domain to analyze how land functionality can be (sustainably) managed through policy measures mitigating the divergence between objectives of increased agricultural production and land conservation.

Acknowledgments: The research was carried out in the framework of the research project "Agroscenari" (task 6) financed by the Italian Ministry of Agricultural and Forest Policies.

Author Contributions: Recanatesi, F., Clemente, M. and Salvati, L. contributed equally to this work developing the general idea of the study, designing the empirical analysis and discussing the main results. Grigoriadis, E., Ranalli, F. and Zitti, M. contributed to data collection, figures, bibliographic review and editing. 
Conflicts of Interest: The authors declare no conflict of interest.

\section{References}

1. Borras, S.M., Jr.; Franco, J.C. Global land grabbing and trajectories of agrarian change: A preliminary analysis. J. Agrar. Chang. 2012, 12, 34-59. [CrossRef]

2. Cotula, L. The international political economy of the global land rush: A critical appraisal of trends, scale, geography and drivers. J. Peasant Stud. 2012, 39, 649-80. [CrossRef]

3. Nath, R.; Luan, Y.; Yang, W.; Yang, C.; Chen, W.; Li, Q.; Cui, X. Changes in Arable Land Demand for Food in India and China: A Potential Threat to Food Security. Sustainability 2015, 7, 5371-5397. [CrossRef]

4. Özerol, G.; Bressers, H.; Coenen, F. Irrigated agriculture and environmental sustainability: An alignment perspective. Environ. Sci. Policy 2012, 23, 57-67. [CrossRef]

5. Gutzler, C.; Helming, K.; Balla, D.; Dannowski, R.; Deumlich, D.; Glemnitz, M.; Knierim, A.; Mirschel, W.; Nendel, C.; Paul, C.; et al. Agricultural land use changes-A scenario-based sustainability impact assessment for Brandenburg, Germany. Ecol. Indic. 2015, 48, 505-517. [CrossRef]

6. Paroissien, J.B.; Darboux, F.; Couturier, A.; Devillers, B.; Mouillot, F.; Raclot, D.; le Bissonnais, Y. A method for modeling the effects of climate and land use changes on erosion and sustainability of soil in a Mediterranean watershed (Languedoc, France). J. Environ. Manag. 2015, 150, 57-68. [CrossRef] [PubMed]

7. Conacher, A. Land degradation: A global perspective. N. Z. Geogr. 2009, 65, 91-94. [CrossRef]

8. Tanrivermis, H. Agricultural land use change and sustainable use of land resources in the mediterranean region of Turkey. J. Arid Environ. 2003, 54, 553-564. [CrossRef]

9. Verburg, P.H.; van Berkel, D.B.; Doorn, A.M.; van Eupen, M.; van den Heiligenberg, H.A.R.M. Trajectories of land use change in Europe: A model-based exploration of rural futures. Landsc. Ecol. 2009, 25, 217-232. [CrossRef]

10. Sabbi, A.; Salvati, L. Seeking for a Downward Spiral? Soil Erosion Risk, Agro-forest landscape and Socioeconomic Conditions in Italian local communities. Land Use Policy 2014, 41, 388-396. [CrossRef]

11. European Commission. Agriculture, Environment, Rural Development: Facts and Figures-A Challenge For Agriculture; European Commission: Brussels, Belgium, 2005.

12. Thornes, J.B. The Evolving Context of Mediterranean Desertification. In Mediterranean Desertification: A Mosaic of Processes and Responses; Geeson, N.A., Brandt, C.J., Thornes, J.B., Eds.; Wiley: Chichester, UK, 2002; pp. 5-11.

13. Juntti, M.; Wilson, G.A. Conceptualizing desertification in Southern Europe: Stakeholder interpretations and multiple policy agendas. Eur. Environ. 2005, 15, 228-249. [CrossRef]

14. Karamesouti, M.; Detsis, V.; Kounalaki, A.; Vasiliou, P.; Salvati, L.; Kosmas, C. Land-use and land degradation processes affecting soil resources: Evidence from a traditional Mediterranean cropland (Greece). Catena 2015, 132, 45-55. [CrossRef]

15. Van Vliet, J.; de Groot, H.L.F.; Rietveld, P.; Verburg, P.H. Manifestations and underlying drivers of agricultural land use change in Europe. Landsc. Urban Plan. 2015, 133, 24-36. [CrossRef]

16. MacDonald, D.; Crabtree, J.R.; Wiesinger, G.; Dax, T.; Stamou, N.; Fleury, P.; Lazpita, J.G.; Gibon, A. Agricultural abandonment in mountain areas of Europe: Environmental consequences and policy response. J. Environ. Manag. 2000, 59, 47-69. [CrossRef]

17. Hodge, I. Beyond agri-environmental policy: Towards an alternative model of rural environmental governance. Land Use Policy 2001, 18, 99-111. [CrossRef]

18. Lasanta, T.; Nadal-Romero, E.; Arnáez, J. Managing abandoned farmland to control the impact of re-vegetation on the environment. The state of the art in Europe. Environ. Sci. Policy 2015, 52, 99-109. [CrossRef]

19. Boardman, J.; Poesen, J.; Evans, R. Socio-economic factors in soil erosion and conservation. Environ. Sci. Policy 2003, 6, 1-6. [CrossRef]

20. Gellrich, M.; Baur, P.; Koch, B.; Zimmermann, N.E. Agricultural land abandonment and natural forest re-growth in the Swiss mountains: A spatially explicit economic analysis. Agric. Ecosyst. Environ. 2007, 118, 93-108. [CrossRef]

21. Geri, F.; Amici, V.; Rocchini, D. Human activity impact on the heterogeneity of a Mediterranean landscape. Appl. Geogr. 2010, 30, 370-379. [CrossRef] 
22. Lefebvre, M.; Espinosa, M.; Paloma, S. The influence of the common agricultural policy on agricultural landscapes. Agron. Sustain. Dev. 2012, 34, 309-325.

23. Benton, T.; Vickery, J.A.; Wilson, J.D. Farmland biodiversity: Is habitat heterogeneity the key? Trends Ecol. Evolut. 2003, 18, 182-188. [CrossRef]

24. Cerdà, A.; Lavee, H.; Romero-Díaz, A.; Hooke, J.; Montanarella, L. Preface. Land Degrad. Dev. 2010, $21,71-74$. [CrossRef]

25. Detsis, V. Placing land degradation and biological diversity decline in a unified framework: Methodological and conceptual issues in the case of the north Mediterranean region. Land Degrad. Dev. 2010, 21, 413-422. [CrossRef]

26. Lazarus, E.D. Land grabbing as a driver of environmental change. Area 2014, 46, 74-82. [CrossRef]

27. Bisaro, A.; Kirk, M.; Zdruli, P.; Zimmermann, W. Global drivers setting desertification research priorities: Insights from a stakeholder consultation forum. Land Degrad. Dev. 2013, 25, 5-16. [CrossRef]

28. Bowyer, C.; Withana, S.; Fenn, I.; Bassi, S.; Lewis, M.; Cooper, T.; Benito, P.; Mudgal, S. Land Degradation and Desertification; European Parliament: Bruxelles, Belgium, 2009.

29. Imeson, A. Desertification, Land Degradation and Sustainability; Wiley: Chichester, UK, 2012.

30. Ferrara, C.; Salvati, L.; Tombolini, I. An integrated evaluation of soil resource depletion from diachronic settlement maps and soil cartography. Geoderma 2014, 232-234, 394-405. [CrossRef]

31. Xie, H.; Zou, J.; Jiang, H.; Zhang, N.; Choi, Y. Spatiotemporal Pattern and Driving Forces of Arable Land-Use Intensity in China: Toward Sustainable Land Management Using Emergy Analysis. Sustainability 2014, 6, 3504-3520. [CrossRef]

32. Gordon, L.M.; Bennett, S.J.; Alonso, C.V.; Bingner, R.L. Modeling long-term soil losses on agricultural fields due to ephemeral gully erosion. J. Soil Water Conserv. 2008, 63, 173-181. [CrossRef]

33. Zdruli, P. Scientific concepts for an integrated analysis of desertification. Land Degrad. Dev. 2011, 22, $166-183$.

34. Serpa, D.; Nunes, J.P.; Santos, J.; Sampaio, E.; Jacinto, R.; Veiga, S.; Lima, J.C.; Moreira, M.; Corte-Real, J.; Keizer, J.J.; et al. Impacts of climate and land use changes on the hydrological and erosion processes of two contrasting Mediterranean catchments. Sci. Total Environ. 2015, 538, 64-77. [CrossRef] [PubMed]

35. Kelly, C.; Ferrara, A.; Wilson, G.A.; Ripullone, F.; Nolè, A.; Harmer, N.; Salvati, L. Community resilience and land degradation in forest and shrubland socio-ecological systems: Evidence from Gorgoglione, Basilicata, Italy. Land Use Policy 2015, 46, 11-20. [CrossRef]

36. Wainwright, J. Can modelling enable us to understand the role of humans in landscape evolution? Geoforum 2008, 39, 659-674. [CrossRef]

37. Schwilch, G.; Bestelmeyer, B.; Bunning, S.; Critchley, W.; Herrick, J.; Kellner, K.; Liniger, H.P.; Nachtergaele, F.; Ritsema, C.J.; Schuster, B.; et al. Experiences in monitoring and assessment of sustainable land management. Land Degrad. Dev. 2011, 22, 214-225. [CrossRef]

38. Bajocco, S.; Salvati, L.; Ricotta, C. Land degradation vs. fire: A spiral process? Progress Phys. Geogr. 2011, 35, 3-18. [CrossRef]

39. Herrmann, S.M.; Hutchinson, C.F. The changing contexts of the desertification debate. J. Arid Environ. 2005, 63, 538-555. [CrossRef]

40. Stavi, I.; Lal, R. Achieving Zero Net Land Degradation: Challenges and opportunities. J. Arid Environ. 2015, 112, 44-51. [CrossRef]

41. Kosmas, C.; Tsara, M.; Moustakas, N.; Karavitis, C. Identification of indicators for desertification. Ann. Arid Zones 2003, 42, 393-416.

42. Lavado-Contador, J.F.; Schnabel, S.; Gomez-Gutierrez, A.; Pulido-Fernandez, M. Mapping sensitivity to land degradation in Extremadura, SW Spain. Land Degrad. Dev. 2009, 20, 129-144. [CrossRef]

43. Myers, N.; Mittermeier, R.A.; Mittermeier, C.G. Biodiversity hotspots for conservation priorities. Nature 2000, 403, 853-858. [CrossRef] [PubMed]

44. Kairis, O.; Karavitis, C.; Kounalaki, A.; Fasouli, V.; Salvati, L.; Kosmas, K. The effect of land management practices on soil erosion and land desertification in an olive grove. Soil Use Manag. 2014, 29, 597-606. [CrossRef]

45. Barbero-Sierra, C.; Marques, M.J.; Ruiz-Pérez, M.; Escadafal, R.; Exbrayat, W. How is Desertification Research Addressed in Spain? Land Versus Soil Approaches. Land Degrad. Dev. 2015, 26, 423-432. [CrossRef]

46. Basso, B.; de Simone, L.; Ferrara, A.; Cammarano, D.; Cafiero, G.; Yeh, M.; Chou, T. Analysis of contributing factors to desertification and mitigation measures in Basilicata region. Ital. J. Agron. 2010, 5, 33-44. [CrossRef] 
47. Van Zanten, B.T.; Verburg, H.; Espinosa, M.; Gomez-y-Paloma, S.; Galimberti, G.; Kantelhardt, J.; Kapfer, M.; Lefebvre, M.; Manrique, R.; Piorr Raggi, M.; et al. European agricultural landscapes, common agricultural policy and ecosystem services: A review. Agron. Sustain. Dev. 2013, 34, 309-325. [CrossRef]

48. Schulte, R.P.O.; Creamer, R.E.; Donnellan, T.; Farrelly, N.; Fealy, R.; O’Donoghue, C.; O’hUallachain, D. Functional land management: A framework for managing soil-based ecosystem services for the sustainable intensification of agriculture. Environ. Sci. Policy 2014, 38, 45-58. [CrossRef]

49. Biasi, R.; Brunori, E.; Smiraglia, D.; Salvati, L. Linking traditional tree-crop landscapes and agro-biodiversity in Central Italy using a database of typical and traditional products: A multiple risk assessment through a data mining analysis. Biodivers. Conserv. 2015, 24, 3009-3031. [CrossRef]

50. Briassoulis, H. Governing desertification in Mediterranean Europe: The challenge of environmental policy integration in multi-level governance contexts. Land Degrad. Dev. 2011, 22, 313-325. [CrossRef]

51. Wilson, G.A. Community resilience, transitional corridors and macro-scalar lock-in effects. Environ. Policy Gov. 2014, 24, 42-59. [CrossRef]

52. Salvati, L.; Bajocco, S. Land sensitivity to desertification across Italy: Past, present, and future. Appl. Geogr. 2011, 31, 223-231. [CrossRef]

53. Hill, J.; Stellmes, M.; Udelhoven, T.; Roder, A.; Sommer, S. Mediterranean desertification and land degradation: Mapping related land use change syndromes based on satellite observations. Glob. Planet. Chang. 2008, 64, 146-157. [CrossRef]

54. Gobin, A.; Jones, R.; Kirkby, M.; Campling, P.; Govers, G.; Kosmas, C.; Gentile, A.R. Indicators for pan-European assessment and monitoring of soil erosion by water. Environ. Sci. Policy 2004, 7, 25-38. [CrossRef]

55. Foley, J.A.; DeFries, R.; Asner, G.P.; Barford, C.; Bonan, G.; Carpenter, S.R.; Chapin, F.S.; Coe, M.T.; Daily, G.C.; Gibbs, H.K.; et al. Global consequences of land use. Science 2005, 309, 570-574. [CrossRef] [PubMed]

56. Borrelli, P.; Panagos, P.; Montanarella, L. New Insights into the Geography and Modelling of Wind Erosion in the European Agricultural Land. Application of a Spatially Explicit Indicator of Land Susceptibility to Wind Erosion. Sustainability 2015, 7, 8823-8836. [CrossRef]

57. De Lange, H.J.; Sala, S.; Vighi, M.; Faber, J.H. Ecological vulnerability in risk assessment: A review and perspectives. Sci. Total Environ. 2010, 408, 3871-3879. [CrossRef] [PubMed]

58. Beroya-Eitner, M.A. Ecological vulnerability indicators. Ecol. Indic. 2016, 60, 329-334. [CrossRef]

59. Salvati, L.; Zitti, M. Regional convergence of environmental variables: Empirical evidences from land degradation. Ecol. Econ. 2008, 68, 162-168. [CrossRef]

60. Montanarella, L.; Vargas, R. Global governance of soil resources as a necessary condition for sustainable development. Curr. Opin. Environ. Sustain. 2012, 4, 559-564. [CrossRef]

61. Salvati, L.; Mavrakis, A.; Colantoni, A.; Mancino, G.; Ferrara, A. Complex Adaptive Systems, soil degradation and land sensitivity to desertification: A multivariate assessment of Italian agro-forest landscape. Sci. Total Environ. 2015, 521-522, 235-245. [CrossRef] [PubMed]

62. Istituto Nazionale di Statistica (ISTAT). Circoscrizioni Statistiche; ISTAT: Roma, Italy, 1958. (In Italian)

63. Istituto Nazionale di Statistica (ISTAT). Atlante Statistico dei Comuni; ISTAT: Roma, Italy, 2006. (In Italian)

64. Bakr, N.; Weindorf, D.C.; Bahnassy, M.H.; El-Badawi, M.M. Multi-temporal assessment of land sensitivity to desertification in a fragile agro-ecosystem: Environmental indicators. Ecol. Indic. 2012, 15, 271-280. [CrossRef]

65. Reed, M.S.; Stringer, L.C.; Dougill, A.J.; Perkins, J.S.; Atlhopheng, J.R.; Mulale, K.; Favretto, N. Reorienting land degradation towards sustainable land management: Linking sustainable livelihoods with ecosystem services in rangeland systems. J. Environ. Manag. 2015, 151, 472-485. [CrossRef] [PubMed]

66. Kéfi, S.; Rietkerk, M.; Alados, C.L.; Pueyo, Y.; Papanastasis, V.P.; ElAich, A.; de Ruiter, P.C. Spatial vegetation patterns and imminent desertification in Mediterranean arid ecosystems. Nature 2007, 449, 213-217. [CrossRef] [PubMed]

67. Chasek, P.; Safriel, U.; Shikongo, S.; Fuhrman, V.F. Operationalizing Zero Net Land Degradation: The next stage in international efforts to combat desertification? J. Arid Environ. 2012, 112, 5-13. [CrossRef]

68. Fernandes, E.; Burcroff, R. Sustainable Land Management. Challenges, Opportunities and Trade-offs; The World Bank: New York, NY, USA, 2006.

(C) 2015 by the authors; licensee MDPI, Basel, Switzerland. This article is an open access article distributed under the terms and conditions of the Creative Commons by Attribution (CC-BY) license (http://creativecommons.org/licenses/by/4.0/). 